Research Paper

\title{
RESEARCH ON URBAN SPRAWL TRENDS AND LANDSCAPE CHANGE IN PLEIKU CITY, GIA LAI PROVINCE
}

\author{
Nguyen Ninh Hai ${ }^{1}$, Nguyen Tuan Anh ${ }^{1}$, Tran Nguyen Lam Khuong ${ }^{1}$, \\ Bach Quang Dung ${ }^{2}$, Nguyen Minh $\mathrm{Ky}^{1 *}$
}

\section{ARTICLE HISTORY}

Received: August 12, 2019 Accepted: October 15, 2019

Publish on: October 25, 2019

\section{ABSTRACT}

Urban sprawl is an international phenomenon happening principally in quickly developing areas. A study on the spatiotemporal features of urban sprawl is useful for the sustainable land management, landscape and urban land planning. The present research explores the trends, types and changes of landscape of urban sprawl in the context of a rapid urbanization process in Pleiku city and in the Central Highland of Viet Nam from 2000 to 2019. The results show the expansion of the Pleiku city has witnessed a fluctuation in its land uses through two decades. The rate of land use in residential areas has been increasing by 0.22 percent, infrastructures (0.61 percent $)$, and other land ( 0.41 percent $)$. This assertion is further supported by the rapid reduction of the vacant land (1.14 percent) and agriculture land $(0.21 \%)$. Moreover, three types of urban sprawl are distinguished by analyzing covered urban area maps from the analysis of Satellite data images and current land use maps. Firstly, it is the outlying type with the area of $3.97 \mathrm{~km}^{2}$, almost 62.72 percent of the total newly increased urban area. Secondly, the area of the infilling type is $1.11 \mathrm{~km}^{2}$, which makes up 17.54 percent, and the figure for the edge-expansion area is $1.25 \mathrm{~km}^{2}$, accounting for $19.75 \%$ of the total urban sprawl area. Studying trends and types of urban sprawl are useful to manage and properly allocate for sustainable land resource as well as urban land use planning.

Keywords: Urban sprawl, urban planning, urbanization, Pleiku, sustainable management, landscape.

\section{Introduction}

The term "sprawl" was first used by Earle Draper of the Tennessee Valley Authority in the context of a national conference of planners in 1937 (Maier et al., 2006). Sprawl was referred to as an unaesthetic and uneconomic settlement form. The term of "urban sprawl" was first used in the opening paragraph of an article by the sociologist William Whyte in Fortune magazine in 1958 (Robert, 2002). Planners have since then used the term to categorize an urban development, generating undesired social effects. Urban Economists also adopted the term and added to the debate terms like scatter, leapfrogging and ribbon development.

Urban sprawl is a form of spatial expansion, characterized by low densities, scattered and discontinuous "leapfrog" growth, and isolation of land uses, encouraging the massive use of private vehicles and strip-malls; the form of development is found mainly in open, rural lands on

$\triangle$ Nguyen Minh Ky

Corresponding author: nmky@hcmuaf.edu.vn

${ }^{1}$ Nong Lam University of Ho Chi Minh City - Gia Lai campus, Vietnam

${ }^{2}$ Viet Nam Meteorological and Hydrometeorological Administration, Ha Noi, Vietnam 
the edge of metropolitan areas (Richard, 1989; Ewing, 1997; Burchell et al., 1998; Hadly, 2000). The phenomenon of urban sprawl, often known as suburbanization, started at the end of the industrial era, and it has continued since throughout the world, especially in Western countries (Robert and Clark, 1965; Real Estate Research Corporation, 1974; Edwin and Bruce, 1990). Many new urban patches have emerged from the previous agricultural land and tremendous changes of landscape pattern have taken place within the study period (Lv et al., 2011).

In terms of different urban form, Wilson et al. (2003) have identified three categories of urban growth: infill, expansion, and outlying, with outlying urban growth further separated into isolated, linear branch, and clustered branch growth. The relation to existing developed areas is important when determining what kind of urban growth has occurred. An infill growth is characterized by a non-developed pixel being converted to urban use and surrounded by at least $40 \%$ existing developed pixels. It can be defined as the development of a small tract of land mostly surrounded by urban land-cover (Wilson et al., 2003). Ellman (1997) defines infill policies as the encouragement to develop vacant land in already built-up areas. Infill development usually occurs where public facilities such as sewer, water, and roads has already existed (Wilson et al., 2003). Forman (1995) describes infill attrition as the disappearance of objects such as patches and corridors (Richard, 1995). An expansion growth is characterized by a non-developed pixel being converted to developed and surrounded by no more than $40 \%$ existing developed pixels. This conversion represents an expansion of the existing urban patch (Wilson et al., 2003). Expansion-type development has been called metropolitan fringe development or urban fringe development (Anderson, 2001). Forman (1995) discusses it as edge development, defined as a land type spreading unidirectional in more or less parallel strips from an edge. The analogous land trans- formation is shrinkage, defined as the decrease in size of objects, such as patches (Richard, 1995). Outlying growth is characterized by a change from non-developed to developed landcover occurring beyond existing developed areas (Wilson et al., 2003). This type of growth has been called development beyond the urban fringe (Anderson, 2001). The outlying growth designation is divided into the following three classes: isolated, linear branch, and clustered branch (Wilson et al., 2003).

Vietnam is entering into an important stage of urbanization, space and population in urban areas have increased rapidly (World Bank, 2011), beyond the control of the government, causing several consequences on national land resources, imbalance of environmental ecosystems, imbalance in architectural space, depletion of cultural and historical architectural, and reduction of urban land rapidly, putting great pressure on technical infrastructure (Nguyen Van Hieu, 2017).

Since the 2000s, Vietnam's urban areas have developed in three main trends: (1) The trend of scaling up by the merging of peri-urban areas, urbanized agricultural communes, which are shifting from agriculture to services and handicraft production, the agricultural production part is declining; (2) The trend of expanding urban space by investing in synchronous urban infrastructure, building new modern urban areas creates favorable conditions for expanded urban development; (3) The tendency to extension and encroach on the beaches to construct the new urban areas, both as a means of increasing the urban area, facilitating the development of new modern urban centers and developing an attractive new urban image (Ha Dao, 2019).

A study showed an expansion of Hanoi urban areas from nearly 1000 ha to 6000 ha in the period of 30 years. This trend illustrated Hanoi's urban starts diffusing sprawl development from 1984 to 1992 (Pham and Yasushi, 2008). Meanwhile, another study in Central Highland, the unstable urbanization process has been taking place 
among 5 provinces of this zone, both the volume of urban and the level of urbanization (Hoang, 2014).

In Pleiku city, the study of urbanization trends is as a basis for urban planners and managers to propose the appropriate planning policies, which has not implemented yet. Moreover, the rational land use helps promote the land potential as well as simultaneously achieve the socio-economic development goals of municipal in the coming years. Therefore, there is a need to assess trends and the type of urban expansion and landscape, which is the scientific basis for solving the conflicts on the relationship between urban development and land use, as a basis for proposing future urban development policies. Hence, the study on trends and types of urban expansion in Pleiku City, Gia Lai province is really necessary and towards sustainable urban development. The study in Pleiku city is a representative case study for small and mediumsized cities in Vietnam.

\section{Methodology}

\subsection{The study area}

Pleiku city of Gia Lai province, a small urban area, is located in the North's of Highland area of Viet Nam (Fig.1), between 13 $50^{\prime} 00^{\prime \prime}$ to $14^{\circ} 04^{\prime} 44^{\prime \prime}$ North, $107^{\circ} 49^{\prime} 30^{\prime \prime}$ to $108^{\circ} 06^{\prime} 22^{\prime \prime}$ West. The study area covers 9 communes and 14 wards, which together, cover an area of approximately $260 \mathrm{~km}^{2}$. The current population figure is estimated to be 230.489 inhabitants, with an annual growth rate of 1.4 percent (Pleiku Statistics Office, 2019).

Pleiku city plays a significant role in the Central Highland area of Viet Nam and the whole Indochina area by special location lies on the crucial gird of National Road No. 14, No. 19 and Ho Chi Minh boulevard, which are lifeblood roads to connect the whole country and Indochina area (Tran, 2019). In addition, the city is nearly to both Le Thanh (between Viet Nam and Cambodia) and Ngoc Hoi (between Viet Nam, Laos and Cambodia) international border gates, significant routes to transport products from
Laos and Cambodia to maritime ports of Viet Nam.

Pleiku city is one of the most economically dynamic city in Gia Lai province since the start of the economic reform in 1986. Socio-economic development and rapid urbanization have led to a significant transformation in the pattern of land use. The growing need for housing to accommodate the increasing population has led to an ever-growing urban expansion through the encroachment of non-urban land, especially agricultural land. During this period, a large amount of fertile agricultural land was transformed into other purposes in Pleiku because of rapid urbanization and weak land management.

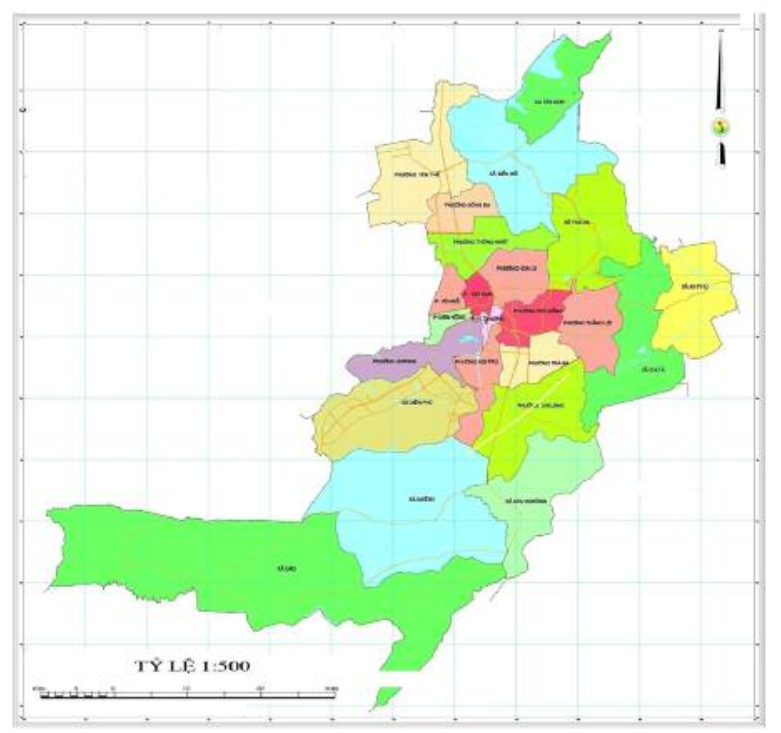

Fig. 1. Location of study area

\subsection{Research methodology}

\subsubsection{Data collection method}

The data were collected into two datasets, one for from primary and secondary data. Primary data were collected by observation and aerial photographs including the Satellite data via website http://.www.earthexplorer.usgs.gov. A satellite image of 2019 was created to cover the study area. Moreover, the study carried out a ground observation in study areas on October 13-26, 2019, and recorded for 130 images. These locations determined in place of urban sprawl.

Secondary data were collected from local authorities within Pleiku city and Gia Lai 
province, such as Land use status quo map (LUSM) from the Department of Natural Resource and Environment (DONRE), a map that demonstrated the distribution of various types of land at a specified time, and was made according to each administrative unit (The National Assembly, 2013). A map of LUSM at scale 1:10.000 was covering the city in 2019 to determine the residential areas, produced by the DONRE and converted into a digital format. Similarly, demographic data were obtained from the People's Community of Pleiku city. Population data from Statistical Yearbook of 2000, 2005, 2010, 2015 and 2019 were used. In addition, the documents showed the patterns of physical and socioeconomic change of the municipal such as population and density, sectors of economy growth, infrastructures, transportation, recreation, urban open were gained from Department of Agricultural and Rural development (DARD), Department of Plan and Invest (DPI), Department of Transportation (DOT) and was aggregated by authors.

\subsubsection{Data analysis}

A free software environment for statistical computing and graphics supported by the $\mathrm{R}$ Foundation for Statistical Computing was used to analyses data and to illustrates several graphical of figures. In addition, a free and open source cross platform desktop geographic information system (QGIS) application that supports viewing, editing and exporting graphical map of Pleiku urban sprawl.

In order to figure out the number of land use trends and the occupied land scale, Microsoft Excel was employed to carry out.

\subsubsection{Approach and methods}

This study is a first attempt to determine land use trends types in Pleiku urban during the past two decades from a landscape perspective. The local review studied documents such as the Land use status quo map in 2000 and 2019 (Pleiku Department of Natural Resources and Environment, 2019).

In term of the approach and methodology, to classify the types of urban sprawl in Pleiku town, the study used the method of literature review and based on the framework of Wilson et al. (2003) and Jun et al. (2011). A metric T was defined for calculating the ration between the length of common edge of newly developed urban patches and existing urban patches as:

$$
\mathrm{T}=\mathrm{Lc} / 1
$$

where Lc $(\mathrm{km})$ is the length of the common edge between a newly developed urban patch and an existing urban patch, $1(\mathrm{~km})$ is the perimeter of the newly developed urban patch. The value of $\mathrm{T}$ is between 0 and 1 . If $\mathrm{T}>0.5$, it means that at least $50 \%$ of the new urban patches is surrounded by the old urban square, and it represents the infilling type (Fig. 2a); if $0<\mathrm{T}$ the new urban patches develop from the edge of the old urban covers, and the common length is less than $50 \%$ of its frontier. This type is edge expansion (Fig. 2b) or shrinkage (Richard, 1995); if $\mathrm{T}=0$, it means that the new urban areas have no spatial association with the old urban patches, and this is outlying type (Fig. 1c) with outlying urban growth further separated into isolated, linear branch, and clustered branch growth (Fig. 3) (Richard, 1989; Wilson et al., 2003). The distance to existing developed areas is important when determining what kind of urban growth has occurred (Karen and Michail, 2005; Basudeb,

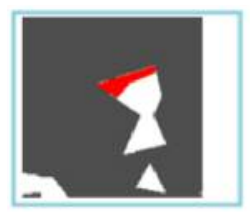

2010)!(a)



(b)

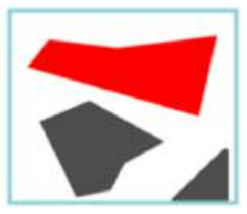

(c)
Old - urban New-urban

Fig 2. The three types of urban sprawl (a) Infilling type, (b) Edge expansion, (c) Outlying type

In addition, other documents reviewed include the sectors of socio-economic development, infrastructural, residential, commercial, industrial, transportation, recreation, urban open and so forth to identify the major stakeholders 


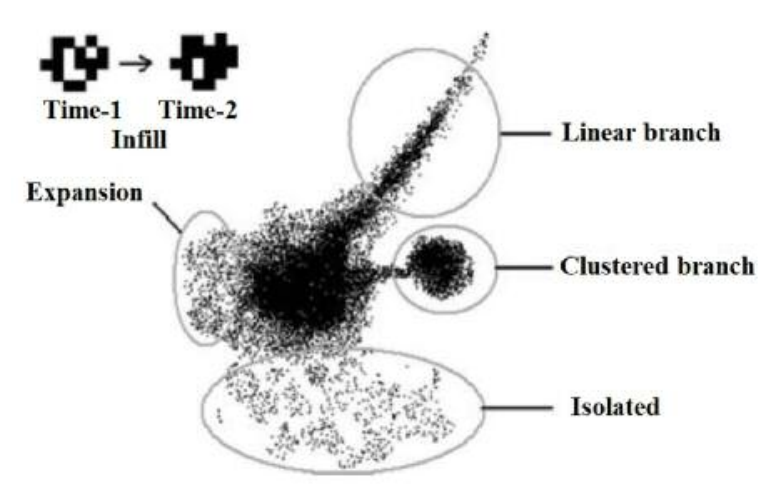

Fig. 3. Schematic diagram of outlying urban growth pattern (Basudeb, 2010)

\section{Results and discussion}

\subsection{Trends of physical growth of Pleiku city}

Land use analysis in Table 1 shows that between 2000 and 2019, the development of Pleiku city has witnessed changes in land uses. The significance of the change in the land uses as a result of urban sprawl has been discussed and it has significantly affected farming lands in the area.

Firstly, the residential land area increased quickly and continuously during the period shown, enlarged by nearly $12.17 \mathrm{~km}^{2}$, equivalent to $8.29 \%$ (in 2000 , it was only $2.47 \%$, of course, it reached $10.76 \%$ in 2019), an average increase of $0.64 \mathrm{~km}^{2} /$ year. The main reason was determined by the rapid increase in the population of the nuclear family process as well as free migration to find agricultural production materials of ethnic minorities in the North and migration from rural to urban (Katherine, 2010) in the region over two decades (from 135,000 in 2000 to 254.802 people in 2018), an increase of 119,802 people.

Secondly, land use of infrastructure increased rapidly and continuously throughout the study period, accounting for only $4.64 \%$ in 2000 but reaching $11.20 \%$ in 2019 , an increase of 2.5 times (equivalent to $14.43 \mathrm{~km}^{2}$ ) within 19 years, an average increase of $0.76 \mathrm{~km}^{2} /$ year. This transformation is still a trend up to now, with the reason for developing infrastructure for the transition of economy from agriculture to industry and services according to the city's develop- ment orientation (Gia Lai Government, 2005 and 2018), typical projects such as roads systems of Ho Chi Minh (phase 2); bypasses of Pleiku city; school system (branch of Nong Lam University; Chau A - Thai Binh Duong school; Nguyen Chi Thanh school); service systems likes HAGL hotel, Duc Long hotel, etc.).

Thirdly, service and commercial land increased by $1.09 \%$ in the period of 19 years, in 2000 it accounted for only $0.08 \%$ but reached $1.17 \%$ in 2019 , an increase of 15 times (equivalent to $2.13 \mathrm{~km}^{2}$ ), and equivalent to an average increase of $0.12 \mathrm{~km}^{2} /$ year. The main force to increase commercial land was the factor of population, combining with policies in investment and development of infrastructural and housing, which requires investors to continuing in expanding and upgrading their business systems. For example, household furniture, office equipment on Pham Van Dong street; interior decoration materials on Tran Phu and Phan Dinh Phung; beauty services, cosmetics business, clothes, fashion shoes on Thong Nhat, $\mathrm{Cu}$ Chinh Lan streets; markets in Chu A commune, Hoa Lu ward on Cach Mang Thang Tam street.

Looking at land use trends, the research illustrates that increased land area was mainly transferred from agricultural land and vacant land. On the one hand, the land for agriculture (Land of forests and other agriculture) contributed significantly more to infrastructural and residential land in Pleiku city than the others. For example, land of forests decreased gradually, with $3.07 \%$, equivalent to $5.66 \mathrm{~km}^{2}$, an average reduction of $0.30 \mathrm{~km}^{2} /$ year). In addition, the rate of decrease of the other farming land was 25.81 percent of total conversion area through 19 years, equivalent to $63.08 \mathrm{~km}^{2}$, an average reduction of $3.32 \mathrm{~km}^{2} /$ year).

On the other hand, over the time period in question the amount of reduction of vacant land was steadily become more important, actually having a change of 17.49 percent, respectively $33.89 \mathrm{~km}^{2}$, an average reduction of 1.78 $\mathrm{km}^{2} /$ year, which was about 0.6 times lower than the rate of cultivated parcel $(28.88 \%)$. This is 
Research on urban sprawl trends and landscape change in Pleiku city, Gia Lai province

due to the transformation from vacant land to an- nual crops and perennial trees.

Table 1. Land use inventory of the Pleiku city

\begin{tabular}{|c|c|c|c|c|c|c|c|c|}
\hline \multirow{2}{*}{ ID } & \multirow{2}{*}{ Land Use Types } & \multicolumn{5}{|c|}{ Years } & \multicolumn{2}{|c|}{$\begin{array}{c}\text { Change } \\
2019 / 2000\end{array}$} \\
\hline & & 2000 & 2005 & 2010 & 2015 & 2019 & $\begin{array}{l}\text { Area } \\
\left(\mathbf{k m}^{2}\right)\end{array}$ & $\%$ \\
\hline A & Agricultural land uses categories & 175.46 & 174.51 & 178.42 & 189.36 & 188.81 & 14.30 & 5.49 \\
\hline 1 & Land for cultivation of annual crops & 33.37 & 35.79 & 49.05 & 54.57 & 53.30 & 17.51 & 7.64 \\
\hline 2 & Land for cultivation of perennial trees & 39.64 & 42.84 & 96.47 & 111.53 & 108.08 & 65.24 & 26.25 \\
\hline 3 & Land of forests & 34.84 & 32.50 & 32.19 & 22.69 & 26.84 & -5.66 & -3.07 \\
\hline 4 & Aquaculture land & 0.20 & 0.20 & 0.35 & 0.49 & 0.49 & 0.29 & 0.11 \\
\hline 5 & Other agricultural land & 67.41 & 63.18 & 0.36 & 0.08 & 0.10 & -63.08 & -25.81 \\
\hline $\mathrm{B}$ & Other land uses categories & 37.84 & 50.51 & 56.51 & 66.45 & 70.10 & 19.59 & 12.37 \\
\hline 1 & Residential & 6.43 & 15.88 & 24.51 & 27.48 & 28.05 & 12.17 & 8.29 \\
\hline 2 & Office land & 0.23 & 0.89 & 1.17 & 1.63 & 2.13 & 1.24 & 0.73 \\
\hline 3 & Commercial land & 0.20 & 0.72 & 1.15 & 1.80 & 3.05 & 2.33 & 1.09 \\
\hline 4 & Green and sport areas (open spaces) & 0.10 & 0.41 & 0.57 & 0.69 & 0.72 & 0.31 & 0.24 \\
\hline 5 & Industrial land & 0.72 & 1.61 & 1.61 & 1.43 & 1.43 & -0.18 & 0.27 \\
\hline 6 & Infrastructures land & 12.10 & 14.78 & 20.25 & 27.62 & 29.21 & 14.43 & 6.56 \\
\hline 7 & Others land & 18.06 & 16.22 & 7.25 & 5.80 & 5.51 & -10.71 & -4.81 \\
\hline $\mathrm{C}$ & Vacant land (unused land) & 47.48 & 35.75 & 25.84 & 4.96 & 1.86 & -33.89 & -17.49 \\
\hline
\end{tabular}

These fluctuations in the structure of the land peri-urban status of these peripheral settlements, use are consistent with the socio-economic de- and increasing in infrastructures of roads, velopment in Pleiku city. The rapid physical ex- schools, hospitals and so forth, resulting in inpansion of the city explains the current creasing consumption of sub-urban land.

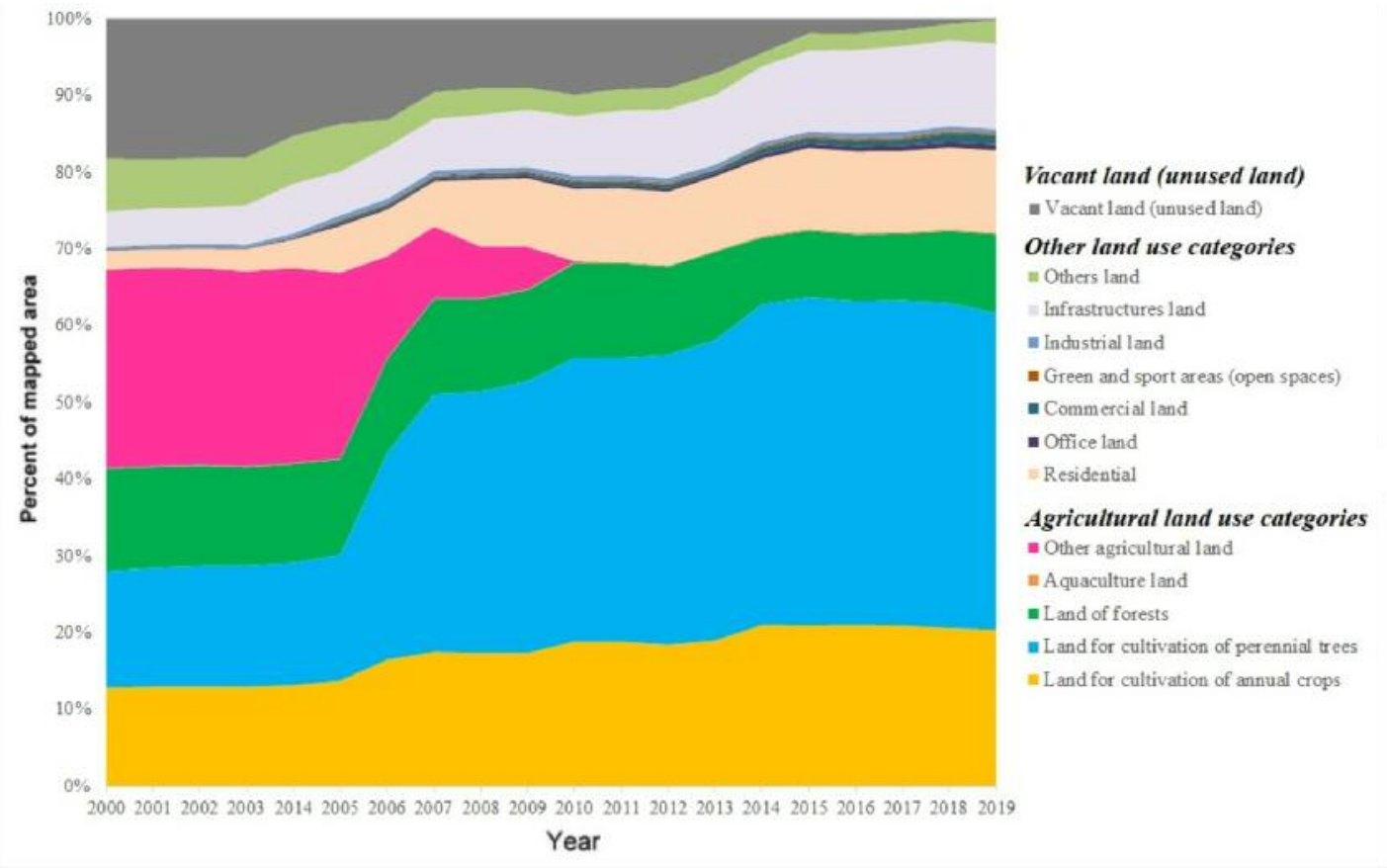

Fig. 4. Land use trends in Pleiku city 


\section{Landscape Characteristics in 2019}

The term landscape characteristic equally to land use type in urban areas. Pleiku city landscape is concerns on the degraded and loss of agriculture land in area. It is not concerned with what landscape makes one landscape better or worse than another.

Agricultural land declined to $0.21 \%$ of the total area and was typically isolated on the peripheries of the study zone, which had a very patchy and scattered configuration (Fig. 5). The built-up areas became the most predominant land-use type in the urban landscape of Pleiku
$28.88 \%$ of the total (Table 2 ).

In the larger context, built-up areas expanded primarily along the National Road No.19 and National Road No. 14 parallel to the development of the transportation network. In particular, the urban spread in a linear pattern toward the Tan Son, Bien Ho, Dien Phu and Phu An communes. In this process, the low-density residential character of the study area was mostly

replaced with high-density mixed uses and was mainly situated on the slopes of hills in the northern part of the study area.

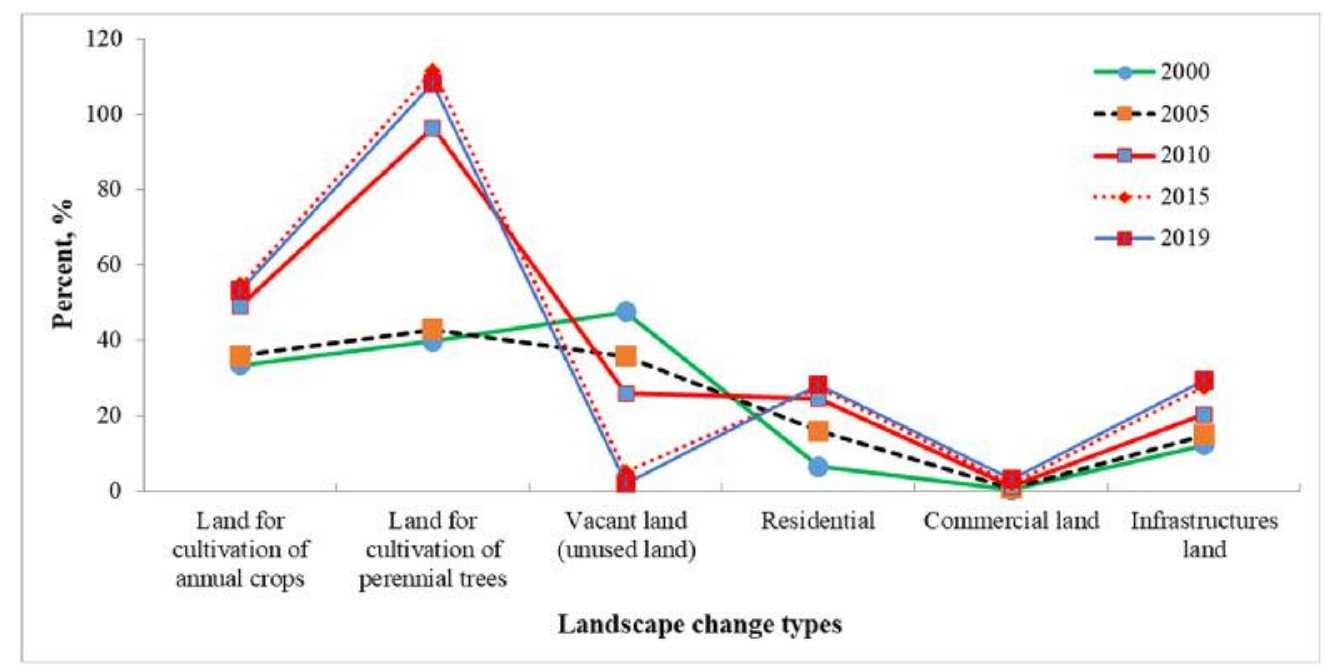

Fig. 5. Landscape change types in Pleiku city

\subsection{Types of urban sprawl and areas af- fected in Pleiku city}

Detailed analysis of the newly expanded urban areas revealed the general trends of urbanization process and pointed out the configuration of the different urban sprawl types in Pleiku city between 2000 and 2019. The types of three kind of urban growths are illustrated in Fig. 6 and Table 2.

The Fig. 6 shows that the types of urban sprawl in Pleiku are similar to framework of Wilson et al. (2003) and Jun et al. (2011). These three types of urban growth have been visualized in this study including infilling type, edge expansion and outlying type.

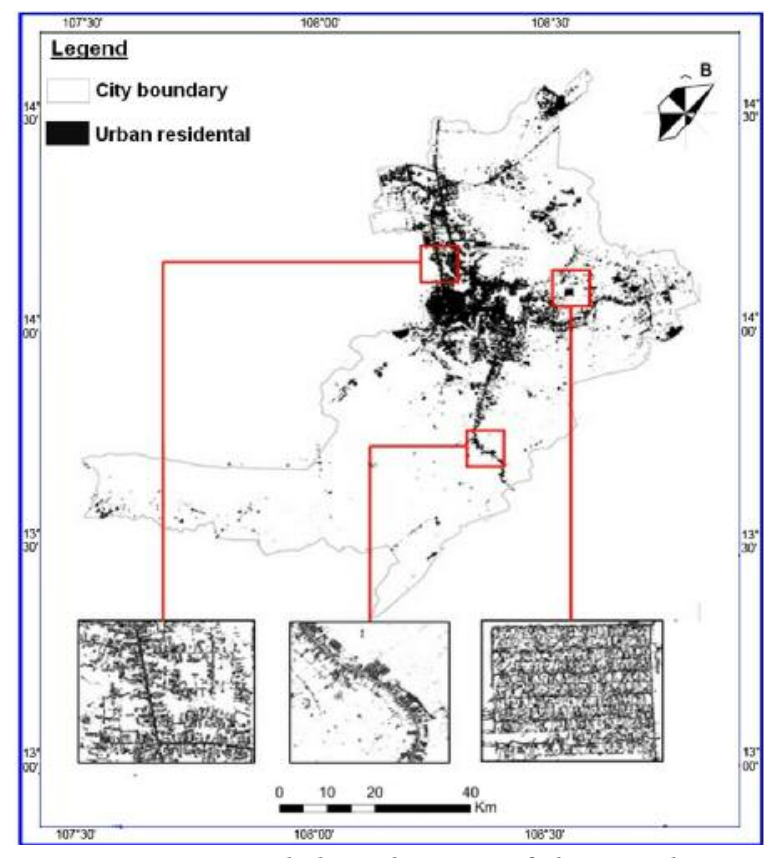

Fig. 6. Spatial distribution of three urban growth types in study area in Pleiku city 
Research on urban sprawl trends and landscape change in Pleiku city, Gia Lai province

Table 2. Land areas of urban sprawl

\begin{tabular}{|c|c|c|c|c|}
\hline $\begin{array}{l}\text { Types of } \\
\text { urban } \\
\text { sprawl }\end{array}$ & Zones & $\begin{array}{l}\text { Area } \\
\left(\mathrm{km}^{2}\right)\end{array}$ & $(\%)$ & $\begin{array}{c}\text { Communes/ } \\
\text { Wards }\end{array}$ \\
\hline \multirow{3}{*}{$\begin{array}{l}\text { Infilling } \\
\text { type }\end{array}$} & I1 & 0.56 & 8.85 & \multirow{4}{*}{$\begin{array}{c}\text { Thong Nhat } \\
\text { Dong Da } \\
\text { Ia Kring }\end{array}$} \\
\hline & $\mathrm{I} 2$ & 0.3 & 4.74 & \\
\hline & $\mathrm{I} 3$ & 0.25 & 3.95 & \\
\hline Sum & & 1.11 & 17.54 & \\
\hline \multirow{3}{*}{$\begin{array}{l}\text { Edge } \\
\text { expansion }\end{array}$} & E1 & 0.35 & 5.53 & \multirow{4}{*}{$\begin{array}{c}\text { Thong Nhat } \\
\text { Dien Phu } \\
\text { Hoa Lu }\end{array}$} \\
\hline & E2 & 0.35 & 5.53 & \\
\hline & E3 & 0.55 & 8.69 & \\
\hline Sum & & 1.25 & 19.75 & \\
\hline \multirow{10}{*}{ Outlying } & In1 & 0.46 & 7.27 & Bien Ho \\
\hline & In2 & 0.46 & 7.27 & Yen The \\
\hline & In3 & 0.31 & 4.90 & Tra Da \\
\hline & L1 & 0.52 & 8.21 & Tan Son \\
\hline & L2 & 0.41 & 6.48 & Bien Ho \\
\hline & L3 & 0.33 & 5.21 & Dien Phu \\
\hline & L4 & 0.42 & 6.64 & Phu An \\
\hline & L5 & 0.27 & 4.27 & Chu Hdrong \\
\hline & N1 & 0.36 & 5.69 & Phu Dong \\
\hline & $\mathrm{N} 2$ & 0.43 & 6.79 & Phu Dong \\
\hline Sum & & 3.97 & 62.72 & \\
\hline Total & & 6.33 & 100.0 & \\
\hline
\end{tabular}

From Table 2, it can be seen that the whole city has $6.33 \mathrm{~km}^{2}$ and divided into 16 urban sprawl zones, accounting for 2.43 percent of total land area and 22.57 percent of total residential areas.

The comparison among the three sprawl types, as the majority sprawl - outlying sprawl reach at $3.97 \mathrm{~km}^{2}$ and became the main sprawl type, which makes up 62.72 percent of urban sprawl areas. In term of edge expansion, the second type of urban sprawl is $1.25 \mathrm{~km}^{2}$, which makes up 19.75 percent. With regard to the infilling type, this type is $1.11 \mathrm{~km}^{2}$, which are the smallest one with only 17.54 percent.

\subsubsection{Infilling type}

As for the infilling type, its area was smallest in urban sprawl. It was prominent where expansion occurred in the infilling of the remaining open spaces within urban areas.

This study has revealed that the infilling urban sprawl regions consist of Thong Nhat, Dong Da and Ia Kring wards with three locations (from I1 to I3), as shown in Fig. 7, which were transformed non-urban lands (Lands of Peren- nial trees and Annual crops) within the urban region, made them more compact, and also slightly changed urban boundaries between Pleiku city and neighboring districts (Chu Pah and Ia Grai).

In conclusion, in terms of infilling sprawl, the relatively corresponded to sustainable sprawl types (Roberto et al., 2002). The alternation of dominative sprawl types indicated that urban expansion was becoming "relative" and "sustainable" when we consider the previous "waste" character in land use.

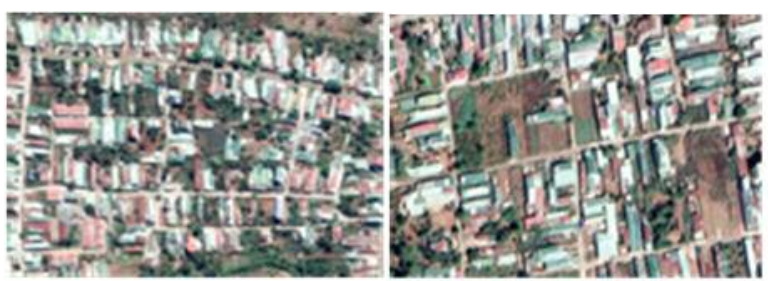

Fig. 7. Infilling type in Thong Nhat and Dong Da wards

\subsubsection{Edge expansion}

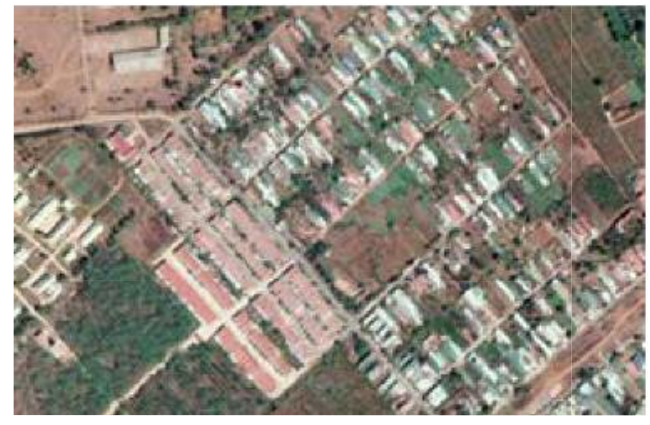

Fig. 8. . Edge type in Hoa Lu ward

The edge enlargement sprawl, which was practically saturated and compact, was the second major sprawl type as shown in Fig. 8. Edgeexpansion emerged mostly in the adjacent urban fringe (Nick et al., 2006). The most sprawl type, which accounted for 19.75 percent of the total sprawl areas, was the edge expansion sprawl in Thong Nhat ward, and Dien Phu, Chu Hdrong communes (from E1 to E3), where land was ready to develop from the edge of the pre-developed area (Duong et al., 2018).

\subsubsection{Outlying type}

The outlying sprawl, which includes insolated type, linear branch and nucleated branch, has been the summing almost 62.72 percent of 
the whole study area, which was considered to be the majority sprawl type. Development outside the main urban region was a reflection of rural towns adopting strategies to establish development or industrial zones (Karen and
Michail, 2005). Outlying characterized the newly scattered development that was far away from the pre-developed urban zone which is described below:

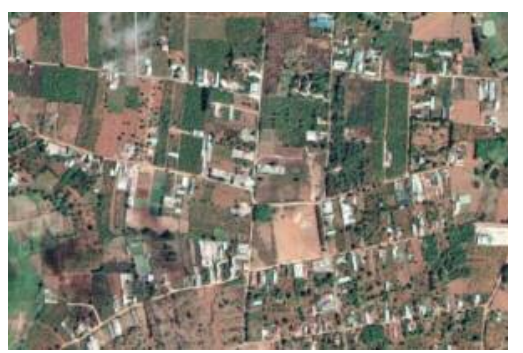

(a)

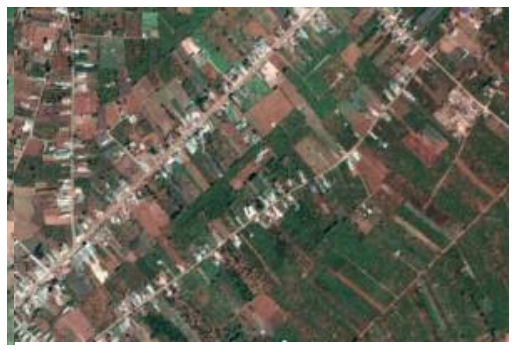

(b)

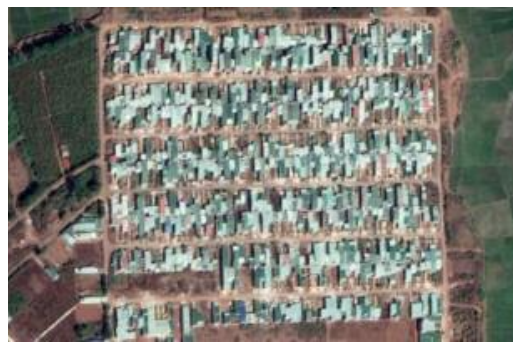

(c)

Fig. 9. Outlying types in Pleiku city (a) Insolated expansion type, (b) Linear spreading out type, (c) Nucleated type

\section{a) Isolated type}

The whole city has $1.23 \mathrm{~km}^{2}$ isolated areas, which accounted for 20.34 percent of urban sprawl in Bien Ho commune, Yen The and Tra Da wards (from I1 to I3), as shown in Fig. 9a. Dispersed settlements are ones where the houses are spread out over a wide area. They are often the homes of farmers and can be found in periurban areas of Pleiku city.

b) Linear branch

As far as the other types of urban growth are concerned, linear settlements in study area, the buildings are constructed in lines shape, often next to a geographical feature in a lake shore, a stream or following a road in Tan Son, Bien Ho, Dien Phu, Phu An and Chu Hdrong communes, as shown in Fig. 9b. The number of liner settlements has $1.95 \mathrm{~km} 2,30.81$ percent of total urban sprawl area, is considerably more common than insolated type, which makes up 20.34 percent.

Most urban sprawl sites are located around the sub-urban areas of Pleiku city, within or near villages of ethnic minorities.

c) Nucleated or Clustered branch

The nucleated sprawl, where buildings are close together, often clustered around a central point, was the third sprawl type in outlying which as shown in Fig. 9c. The area of the sprawl type is $0.79 \mathrm{~km} 2$, which accounts for
12.48 percent of the total sprawl areas, was the development sprawl in Hoa Lu ward (N1 and N2). The location of nucleated settlement can be determined by a range of factors, including being easy to defend, close to a water supply or located at main routes. This proximity makes communication quicker and easier than in linear and dispersed settlements. Because people are closer together, it is also easier to do daily tasks such as buying and selling of goods and services.

\section{Conclusions and recommendations}

Spatial and temporal studies on urban sprawl or urban areas expansion are necessary for land planning and urban planning in Viet Nam, which is experiencing a rapid increase of land demand for construction in the context of economic development and population growth. Understanding the change in the spatial configuration of urban areas over time is essential for identifying the effects of urban sprawl and landscape.

In term of land use, the results of the assessment of land use trends in the period of 20002019 show that the land use and landscape of Pleiku city has changed rapidly and significantly. Perhaps the biggest change has been in the overall of settlement and infrastructures plots. Accompanying this shift in the composition of land use trends has been a changing in its type, most notably a reduction outside of agriculture in term 
of land for cultivation of annual crops, perennial trees and vacant land. In general, the trend of land use fluctuations in the region is consistent with socio-economic development of Pleiku city.

Besides, the results revealed a remarkable expansion of urban areas between 2000 and 2019. The different types of urban sprawl showed a tendency of leading the shape of the whole landscape composed by the three different sprawl types to become regular in outline in distribution. According to the sprawl quantifying mechanism, outlying sprawl was often appearing at outside the chief inner-city area, that extended urban coverage, have accelerated the increase of urban size significantly. The expanse of infilling was gradually transformed non-urban parcels within the urban region for municipal use, the urban patches gather gradually to be more compact. The edge expansion was to develop from the edge of the pre-developed area, the pre-constructed urban areas or far from the core areas.

Finally, because of the inadequate analysis of urban sprawl and its effects, the mechanism and manifestation of urban sprawl was not explained in this study, thereby needing further consideration. The continuing study on urban sprawl in rapidly developing regions should concentrate on the effects of the different sprawl types on sustainable land use and urbanization, distribution of the different sprawl types. The links between socioeconomic driving forces and urban sprawl configuration with social, economic, and environmental effects have to be clearly understood, which may play an important role in urban planning in Pleiku city.

\section{References}

1. Anderson, H., 2001. Development at the Urban Fringe and Beyond: Impacts on Agriculture and Rural Land. ERS Agricultural Economic Report (No. 1473-2016-120733).

2. Basudeb, B., 2010. Analysis of Urban Growth and Sprawl from Remote Sensing Data. Springer Publishing Company, Incorporated.
3. Burchell, R.W., Shad, N.A., Listokin, D., Phillips, H., Downs, A., Seskin, S., Davis, J.S., Moore, T., Helton, D., Gall, M., 1998. The Costs of Sprawl--Revisited. Transit Cooperative Research Program (TCRP) Report 39, Transportation Research Board, Washington.

4. Duong, H.N., Christopher, A.L., Tomoaki, M., Jefferson, M.F., 2018. Quantifying urban growth patterns in Hanoi using landscape expansion modes and time series spatial metrics. PLoS ONE, 13 (5): e0196940.

5. Ellman, T., 1997. Infill: The Cure for Sprawl? Arizona Issue Analysis, 146: 21.

6. Edwin, S.M., Bruce, W.H., 1990. Urban Economics. Land Economics, 66: 224-226.

7. Ewing, R., 1997. Is Los Angeles-Style Sprawl Desirable?. J. Am. Plann. Assoc., 63 (1): 107-126.

8. Gia Lai Government, 2005. Master plan on urban development of Pleiku until 2020. Gia Lai.

9. Gia Lai Government, 2018. Adjustment report on construction master plan of Pleiku city to 2030, vision to 2050. Gia Lai.

10. Ha Dao, 2019. Three development trends of Vietnam urban, Construction Newspaper, accessed on 15th Oct 2019 <http:/www.baoxaydung.com.vn/3-xu-huong-phat-trien-cua-do-thiviet-nam-265454.html>.

11. Hadly, C.C., 2000. Urban Sprawl: Indicators, Causes, and Solutions. Doc. Prep. Bloomingt. Environ. Comm.

12. Hoang, B.T., 2014. Developing the Central Highlands Urban System in Vietnam. Journal of Vietnam Social Science, 5 (78): 49-59.

13. Katherine, V.M.F., 2010. Internal migration - Opportunities and challenges for socioeconomic development in Vietnam. The United Nations Development Program in Viet Nam, Hanoi.

14. Karen, C.S., Michail, F., 2005. Quantifying Spatiotemporal Patterns of Urban Land-use Change in Four Cities of China with Time Series Landscape Metrics. Landscape Ecology, 20 (7): 871-888. 
15. Lv, Z.Q., Dai, F.Q., Sun, C., 2011. Evaluation of urban sprawl and urban landscape pattern in a rapidly developing region. Environ Monit Assess., 184 (10): 6437-48.

16. Maier, G., Franz, G., Schrock, P., 2006. Urban sprawl. How useful is this concept?. Proceedings of ERSA conference papers (No. ersa06p105). European Regional Science Association.

17. Nick, G., Marco, B., Johan, A., 2006. Planning on the edge: England's rural - Urban fringe and the spatial-planning agenda. Environment and Planning B: Planning and Design, 33 (3): 457-476.

18. Nguyen, V.H., 2017. Solutions to develop cities in Vietnam toward the sustainable way. Journal of Industry and Trade, 4: 5.

19. Pham, M.H., Yasushi, Y., 2008. Characterizing the urban growth of Hanoi, Nagoya, and Shanghai City using remote sensing and spatial metrics. Geoscience and Remote Sensing Symposium, Nagoya University, Japan, 5: 5-9.

20. Pleiku Statistics Office, 2019. Statistical Yearbook of Pleiku city 2018, Gia Lai.

21. Pleiku Department of Natural Resources and Environment, 2019. Map of land use status of Pleiku city in 2019, Gia Lai.

22. Real Estate Research Corporation, 1974. The Costs of Sprawl, Detailed Cost Analysis. U.S. Government Printing Office.

23. Richard, B.P., 1989. Density and Urban Sprawl. Land Economics, 65 (3): 193-204.
24. Richard, T.T.F., 1995. Land mosaics: The ecology of landscapes and regions. Cambridge University Press.

25. Robert, W.W., 2002. Fiscalisation of Land Use, Urban Growth Boundaries and Noncentral Retail Sprawl in the Western United States. Sage Publ. Ltd, 39 (8): 1307-1327.

26. Robert, O.H., Clark, W.A.V., 1965. The Nature and Economics of Urban Sprawl. Land Economics, 41: 1-9.

27. Roberto, C., Maria, C.G., Paolo, R., 2002. Urban mobility and urban form: The social and environmental costs of different patterns of urban expansion. Ecol. Econ., 40 (2): 199-216.

28. The National Assembly, 2013. Vietnam Land Law 2013 - Law No. 45/2013/QH13, Hanoi.

29. Tran, X.Q., 2019. The target of Pleiku City towards to the Type I, Gia Lai Online, acessed on $14^{\text {th }}$ Oct 2019 $<$ https: / / baogialai.com.vn/chan nel/9044/201902/pleiku-huong-den-muc-tieudo-thi-loai-i-5619509/index.htm>.

30. Wilson, E.H., James, D.H., Daniel, L.C., Michael, P.P., Chester, A., 2003. Development of a Geospatial Model to Quantify, Describe and Map Urban Growth. Remote Sens. Environ., 86(3): 275-285.

31. World Bank, 2011. Evaluation of urbanization in Vietnam. WB, Washington, D.C., United States. 